\title{
FACTORS INFLUENCING EMPLOYEE GREEN BEHAVIOUR - AN INVESTIGATIVE STUDY ON RASHTRIYA ISPAT NIGAM LTD., VISAKHAPATNAM, A.P
}

\author{
${ }^{1}$ Dr. V. Tulasi Das, ${ }^{2}$ Smt. A. Sreelakshmi \\ ${ }^{I}$ Chairman BoS (PG) in HRM, Dept. of HRM, Acharya Nagarjuna University, Guntur- 522 510, A.P. \\ ${ }^{2}$ Research Scholar, Dept. of HRM, Acharya Nagarjuna University, Guntur-522 510, A.P.
}

\section{ABSTRACT}

DOI No: 10.36713/epra8038

Article DOI URL: https://doi.org/10.36713/epra8038

In order to help offset continuing environmental degradation in the 21st century, humans will have to significantly alter their habits (Howard, 2000; Oskamp, 2000; Winter, 2000). These altered habits cannot consist of merely doing the right thing every now and then; rather, they must be consistent, persistent efforts to move away from inherently wasteful and damaging behaviours and to move towards conservation-oriented or environmentally responsible behaviours (ERB). This environmentally responsible behaviour requires continuous motivation and training. This rigorous motivation and training to whole society cannot be provided by the government alone. But this can be implemented by the organisations to enhance organisational culture and societal wellbeing. In this context current article investigates the factors influencing employee green behaviour in Rashtriya Ispat Nigam Ltd.

KEYWORDS: Environmentally Responsible Behaviour, Employee Green Behaviour, Pollution, Recycling, Training, Motivation.

\section{INTRODUCTION}

"Green behaviour", also known as "environmentally friendly behaviour," refers to a series of actions that promote environmental protection (Unsworth et. al., 2013). Stem (2000) defines it as an act that reduces harm to the natural environment. Individuals and organizations buy green products, recycle resources and reduce waste production as green activities. One and Dichert (2012) introduced the behaviour of promoting environmental protection to the research in the field of work, which defined the green behaviour of employees. At present, regarding the definition of employee green behaviour, scholars use environmental protection organization citizenship behaviour to explore employee green behaviour (Daily, 2001).
Various environmental problems pose a threat to environmental sustainability, among which global warming, urban air pollution, water shortages, environmental noise, and loss of biodiversity. Many of these problems are rooted in human behaviour (DuNann Winter \& Koger, 2004; Gardner \& Stern, 2002; Vlek \& Steg, 2007), and can thus be managed by changing the relevant behaviour so as to reduce its environmental impacts. Changes in human behaviour are believed to be needed because technical efficiency gains resulting from, for example, energy-efficient appliances, home insulation, and water-saving devices tend to be overtaken by consumption growth (Midden, Kaiser, \& McCalley, 2007). Moreover, physical and technical innovations imply behaviour changes as well because individuals need to accept and 
understand them, buy them, and use them in proper ways.

Geller (2002), argues that promoting behaviour change is more effective when one (1) carefully selects the behaviours to be changed to improve environmental quality, (2) examines which factors cause those behaviours, (3) applies well-tuned interventions to change relevant behaviours and their antecedents, and (4) systematically evaluates the effects of these interventions on the behaviours themselves, their antecedents, on environmental quality and human quality of life.

\section{REVIEW OF LITERATURE}

Mi L et. al., (2020) found that needs-supplies fit only has a positive effect on eco-helping behaviour. This result may be due to the complex mechanisms at play in needs-supplies fit and EGB. It is confirmed that higher needs-supplies fit between employees and organizations will bring higher job satisfaction and organizational commitment (Cable and DeRue, 2002; Bahat, 2020). However, it may not directly promote EGB, rather working indirectly through intermediaries such as job satisfaction and organizational commitment.

Xiaodong Chen et., al (2011) said that the age related impact of pro-environmental behaviour may be explained by the cohort effect (Buttel 1979), where younger Chinese have come of age during a period of intense environmental degradation. Our findings also indicate marital studies since single respondents generally demonstrated more pro-environmental behaviours than married respondents. The additional predictive power of marital status (single respondents were younger than married respondents) over age may relate to time constraints on pro-environmental behaviour imposed by family responsibilities.

Bohlmann, C., van den Bosch, J., \& Zacher, H. (2018), research showed that employees' task performance contributed most to overall job performance ratings, followed by counterproductive work behaviour, organizational citizenship behaviour and employee green behaviour. More broadly, findings suggest that employee green behaviour makes an independent positive contribution to overall job performance ratings, but its influence is weaker than that of other forms of work behaviour.

\section{RESEARCH GAP}

From the literature it is found that there are extensive research evidences of employee green behaviour in steel industry. But employee behaviour mostly depends on organisational culture and it varies with organisation to organisation; in this context this research investigates factors influencing employee green behaviour in the study area.

\section{OBJECTIVES}

- To investigates factors influencing employee green behaviour in the Rashtriya Ispat Nigam Ltd.

- To put forth certain suggestions that have that have been derived from the findings of the study.

\section{SAMPLE AND DATA COLLECTION}

A quantitative approach was followed in this exploratory study. The participants selected for this study consisted of employees of Rashtriya Ispat Nigam Ltd. The sample size of the study is confined to 974. Convenience sampling technique was deployed in sample selection. The respondents were solicited to complete the Employee Green Behaviour Questionnaire.

\section{DATA ANALYSIS KMO (Kaiser-Meyer-Olkin) and Bartlett's test}

Kaiser-Meyer-Olkin (KMO) test is a proportion of how fit present information is for Factor Analysis. The test estimates sampling sufficiency for every factor in the model and for the total model. The measurement is a proportion of extent of variance among variance. The lower the extent, the more fit information is for Factor Analysis. Following Table- 1 shows the results of the KMO and Bartlett's test.

Table- 1: KMO and Bartlett's Test Relating to Employee Green Behaviour among Employees of RINL

\begin{tabular}{|l|l|r|}
\hline \multicolumn{3}{|c|}{ KMO and Bartlett's Test } \\
\hline Kaiser-Meyer-Olkin Measure of Sampling Adequacy. & .961 \\
\hline Bartlett's Test of Sphericity & Approx. Chi-Square & 62269.648 \\
\cline { 2 - 3 } & df & 780 \\
\cline { 2 - 3 } & Sig. & .000 \\
\hline
\end{tabular}

(Source: Primary Data)

The above Table- 1 reveals that KMO value i.e., .961 is neither nearer to zero nor close to one. So, the range is found to be good. Bartlett's test for Sphericity compares correlation matrix (a matrix of Pearson correlation) to the identity matrix. In other words, it checks if there is a redundancy between variables that can be summarized with some factors. Therefore, this test should be momentous (i.e., have a significant value less than 0.05). A significant value from chi-square test shows that for the present data R-matrix is not an identity matrix. Here Bartlett's test for Sphericity is highly significant $(\mathrm{p}<0.001)$, therefore it is concluded that the factor analysis is appropriate. 


\section{COMMUNALITIES}

Initial communalities estimate the differences among each factor accounted for, from all the variables. Extraction communalities values are estimates of the differences in each factor accounted for the variables in the factor solution. Below Table- 2 shows the particulars of communalities of Employee Green Behaviour among Employees of RINL.

Table- 2: Communalities- Employee Green Behaviour among Employees of RINL

\begin{tabular}{|c|c|c|}
\hline \multicolumn{3}{|l|}{ Communalities } \\
\hline & Initial & Extraction \\
\hline $\begin{array}{l}\text { When there is a decision, pick items that are better for the } \\
\text { climate }\end{array}$ & 1.000 & .638 \\
\hline $\begin{array}{l}\text { Fix support issues to forestall accidental pollution and waste } \\
\text { of resources }\end{array}$ & 1.000 & .808 \\
\hline $\begin{array}{l}\text { Not to use single-use, expendable items, for example, paper } \\
\text { towels }\end{array}$ & 1.000 & .808 \\
\hline $\begin{array}{l}\text { Propose ways for different employees to act in a more } \\
\text { ecological agreeable way }\end{array}$ & 1.000 & .714 \\
\hline $\begin{array}{l}\text { Propose new program for the organization which is harmless } \\
\text { to the ecosystem }\end{array}$ & 1.000 & .830 \\
\hline $\begin{array}{l}\text { Expand the life expectancy of office hardware through fix and } \\
\text { support }\end{array}$ & 1.000 & .820 \\
\hline Design new, eco-friendly items & 1.000 & .832 \\
\hline $\begin{array}{l}\text { Voice worries that acting supportive of environment couldn't } \\
\text { hurt the organization }\end{array}$ & 1.000 & .774 \\
\hline $\begin{array}{l}\text { Talk about environment friendly points with fellow } \\
\text { employees }\end{array}$ & 1.000 & 677 \\
\hline $\begin{array}{l}\text { Push the organization's chiefs to take a stronger position on } \\
\text { Climate issues }\end{array}$ & 1.000 & .738 \\
\hline Use new advancements that advantage the climate & 1.000 & .663 \\
\hline Use supplies in environment friendly manner & 1.000 & .796 \\
\hline Never delays a climate related program for business reasons & 1.000 & .834 \\
\hline $\begin{array}{l}\text { Not to purchase organization supplies without thought for } \\
\text { ecological effect }\end{array}$ & 1.000 & .734 \\
\hline Focus on activities that would profit the climate & 1.000 & .758 \\
\hline $\begin{array}{l}\text { Lessen water utilization by turning off faucets when not being } \\
\text { used }\end{array}$ & 1.000 & .872 \\
\hline $\begin{array}{l}\text { Not to utilize wasteful work measures that squander natural } \\
\text { resources }\end{array}$ & 1.000 & .845 \\
\hline Screen the climate effect of workplace processes & 1.000 & .793 \\
\hline Appropriately handle dangerous materials & 1.000 & .644 \\
\hline Give ecologically related writing to other employees & 1.000 & .862 \\
\hline $\begin{array}{l}\text { Offer recognition to other employees for their harmless } \\
\text { conduct towards ecosystem }\end{array}$ & 1.000 & .905 \\
\hline $\begin{array}{l}\text { Reject an alluring venture since it would be awful for the } \\
\text { climate }\end{array}$ & 1.000 & .900 \\
\hline $\begin{array}{l}\text { Change work cycles to decrease adverse consequences on the } \\
\text { climate }\end{array}$ & 1.000 & .906 \\
\hline Tidy up after an ecologically destructive mishap or occasion & 1.000 & .855 \\
\hline Save additional provisions or materials for a future projects & 1.000 & .923 \\
\hline $\begin{array}{l}\text { Help execute new approaches that lessen the organization's } \\
\text { effect on the climate }\end{array}$ & 1.000 & .910 \\
\hline $\begin{array}{l}\text { Decline energy utilization by turning off equipment when not } \\
\text { being used }\end{array}$ & 1.000 & .898 \\
\hline Pick a less advantageous drive since it helps the climate & 1.000 & .908 \\
\hline Reuse paper, plastic, metal cans, and so on & 1.000 & .849 \\
\hline $\begin{array}{l}\text { Not purposely cause pointless harm to the climate through } \\
\text { business related choices }\end{array}$ & 1.000 & .896 \\
\hline
\end{tabular}




\begin{tabular}{|l|r|r|}
\hline $\begin{array}{l}\text { Foster new work measures that utilization less natural } \\
\text { resources }\end{array}$ & 1.000 & .841 \\
\hline Plan another item that contains no unsafe segments & 1.000 & .882 \\
\hline Not to toss recyclable materials into garbage bins & 1.000 & .856 \\
\hline $\begin{array}{l}\text { Not purposely pick advancements that are more hurtful to the } \\
\text { climate }\end{array}$ & 1.000 & .952 \\
\hline $\begin{array}{l}\text { Through work, partake in projects that improve the nearby } \\
\text { climate }\end{array}$ & 1.000 & .884 \\
\hline $\begin{array}{l}\text { Not to prod fellow employees for practices that advantage the } \\
\text { climate }\end{array}$ & 1.000 & .903 \\
\hline $\begin{array}{l}\text { Screen workplace processes for likely wellsprings of } \\
\text { accidental pollution }\end{array}$ & 1.000 & .731 \\
\hline $\begin{array}{l}\text { Give materials another utilization or reason instead of } \\
\text { discarding them }\end{array}$ & 1.000 & .930 \\
\hline $\begin{array}{l}\text { Tell fellow employees that harmless to the ecosystem } \\
\text { practices are powerful }\end{array}$ & 1.000 & .896 \\
\hline $\begin{array}{l}\text { Lessen squander by reusing things, for example, water bottles, } \\
\text { paper, plastic, and so on }\end{array}$ & 1.000 & .827 \\
\hline Extraction Method: Principal Component Analysis. & \\
\hline \begin{tabular}{l} 
(Source: Primary Data) \\
\hline
\end{tabular}
\end{tabular}

The above table-2 gives the communalities of initial and extraction. Principal component analysis deals with the initial hypothesis that all factors are common; so, in the table, values for the initial communalities are 1 for all the factors. The value in the column titled extraction shows the common differences in the data structure. For, factor 3 explains 5.502 per cent 95.2 percent of variance observed is common difference. There is second dimension for observing these communalities is in terms of the ratio of difference explained by the underlying variables.

To understand about the exact level of difference among factors is initially assumed as all communalities are " 1 ". But after the analysis the differentiated values for each variable are found. When there is a decision, pick items that are better for the climate has 63.8 per cent, Fix support issues to forestall accidental pollution and waste of resources has 80.8 per cent, Not to use single-use, expendable items, for example, paper towels 80.8 per cent, Propose ways for different employees to act in a more ecological agreeable way has 71.4 per cent, Propose new program for the organization which is harmless to the ecosystem has 83.0 per cent, Expand the life expectancy of office hardware through fix and support has 82.0 per cent, Design new, eco-friendly items has 83.2 per cent, Voice worries that acting supportive of environment couldn't hurt the organization has 77.4 per cent, Talk about environment friendly points with fellow employees has 67.7 per cent, Push the organization's chiefs to take a stronger position on Climate issues has 73.8 per cent, Use new advancements that advantage the climate has 66.3 per cent, Use supplies in environment friendly manner has 79.6 per cent, Never delays a climate related program for business reasons has 83.4 per cent, Not to purchase organization supplies without thought for ecological effect has 73.4 per cent, Focus on activities that would profit the climate has 75.8 per cent, Lessen water utilization by turning off faucets when not being used has 87.2 per cent, Not to utilize wasteful work measures that squander natural resources has 84.5 per cent, Screen the climate effect of workplace processes has 79.3 per cent, Appropriately handle dangerous materials has 64.4 per cent, Give ecologically related writing to other employees has 86.2 per cent, Offer recognition to other employees for their harmless conduct towards ecosystem has 90.5 per cent, Reject an alluring venture since it would be awful for the climate has 90.0 per cent, Change work cycles to decrease adverse consequences on the climate has 90.6 per cent, Tidy up after an ecologically destructive mishap or occasion has 85.5 per cent, Save additional provisions or materials for a future projects has 92.3 per cent, Help execute new approaches that lessen the organization's effect on the climate has 91.0 per cent, Decline energy utilization by turning off equipment when not being used has 89.8 per cent, Pick a less advantageous drive since it helps the climate has 90.8 per cent, Reuse paper, plastic, metal cans, and so on has 84.9 per cent, Not purposely cause pointless harm to the climate through business related choices has 89.6 per cent, Foster new work measures that utilization less natural resources has 84.1 per cent, Plan another item that contains no unsafe segments has 88.2 per cent, Not to toss recyclable materials into garbage bins has 85.6 per cent, Through work, partake in projects that improve the nearby climate has 88.4 per cent, Not to prod fellow employees for practices that advantage the climate has 90.3 per cent, Screen workplace processes for likely wellsprings of accidental pollution has 73.1 per cent, Give materials another utilization or reason instead of discarding them has 93.0 per cent, Tell fellow employees that harmless to the ecosystem practices are powerful has 89.6 per cent, and Lessen squander by reusing things, for 
example, water bottles, paper, plastic, and so on has 82.7 per cent. Above variables shows the variance in structure. It is shown in Total variance Explained table which is following.

Table- 3: Total Variance Explained- Employee Green Behaviour among Employees of RINL

\begin{tabular}{|c|c|c|c|c|c|c|c|}
\hline \multicolumn{8}{|c|}{ Total Variance Explained } \\
\hline \multirow{2}{*}{$\begin{array}{l}\text { Com } \\
\text { pone } \\
\text { nt }\end{array}$} & \multicolumn{3}{|c|}{ Initial Eigenvalues } & \multicolumn{3}{|c|}{ Extraction Sums of Squared Loadings } & \multirow{2}{*}{$\begin{array}{c}\begin{array}{c}\text { Rotation Sums } \\
\text { of Squared } \\
\text { Loadings }^{\mathbf{a}}\end{array} \\
\text { Total }\end{array}$} \\
\hline & Total & $\begin{array}{c}\% \text { of } \\
\text { Variance }\end{array}$ & $\begin{array}{c}\text { Cumulative } \\
\%\end{array}$ & Total & $\begin{array}{c}\% \text { of } \\
\text { Variance }\end{array}$ & $\begin{array}{c}\text { Cumulative } \\
\%\end{array}$ & \\
\hline 1 & 22.239 & 55.598 & 55.598 & 22.239 & 55.598 & 55.598 & 17.166 \\
\hline 2 & 4.617 & 11.543 & 67.141 & 4.617 & 11.543 & 67.141 & 12.755 \\
\hline 3 & 3.566 & 8.914 & 76.055 & 3.566 & 8.914 & 76.055 & 13.667 \\
\hline 4 & 1.611 & 4.027 & 80.082 & 1.611 & 4.027 & 80.082 & 16.419 \\
\hline 5 & 1.059 & 2.648 & 82.730 & 1.059 & 2.648 & 82.730 & 14.089 \\
\hline 6 & .729 & 1.823 & 84.553 & & & & \\
\hline 7 & .569 & 1.421 & 85.974 & & & & \\
\hline 8 & .568 & 1.419 & 87.393 & & & & \\
\hline 9 & .446 & 1.116 & 88.509 & & & & \\
\hline 10 & .418 & 1.044 & 89.553 & & & & \\
\hline 11 & .364 & .910 & 90.463 & & & & \\
\hline 12 & .343 & .858 & 91.321 & & & & \\
\hline 13 & .305 & .763 & 92.084 & & & & \\
\hline 14 & .273 & .682 & 92.767 & & & & \\
\hline 15 & .255 & .638 & 93.404 & & & & \\
\hline 16 & .241 & .602 & 94.007 & & & & \\
\hline 17 & .221 & .552 & 94.559 & & & & \\
\hline 18 & .190 & .476 & 95.035 & & & & \\
\hline 19 & .182 & .454 & 95.489 & & & & \\
\hline 20 & .176 & .439 & 95.928 & & & & \\
\hline 21 & .161 & .403 & 96.332 & & & & \\
\hline 22 & .158 & .396 & 96.728 & & & & \\
\hline 23 & .141 & .354 & 97.081 & & & & \\
\hline 24 & .137 & .342 & 97.424 & & & & \\
\hline 25 & .128 & .321 & 97.744 & & & & \\
\hline 26 & .114 & .285 & 98.029 & & & & \\
\hline 27 & .105 & .261 & 98.291 & & & & \\
\hline 28 & .098 & .245 & 98.535 & & & & \\
\hline 29 & .083 & .208 & 98.744 & & & & \\
\hline 30 & .075 & .188 & 98.932 & & & & \\
\hline 31 & .071 & .177 & 99.108 & & & & \\
\hline 32 & .063 & .158 & 99.267 & & & & \\
\hline 33 & .057 & .142 & 99.409 & & & & \\
\hline 34 & .055 & .138 & 99.547 & & & & \\
\hline 35 & .050 & .126 & 99.673 & & & & \\
\hline 36 & .038 & .095 & 99.768 & & & & \\
\hline 37 & .032 & .079 & 99.847 & & & & \\
\hline 38 & .027 & .066 & 99.914 & & & & \\
\hline 39 & .024 & .060 & 99.974 & & & & \\
\hline 40 & .010 & .026 & 100.000 & & & & \\
\hline
\end{tabular}

(Source: Primary Data) 
The above Table- 3 shows that Eigen values related with each factor displays the differences explained by that particular linear factor. This table also shows the Eigen values in terms of percentage of difference explain. So, factor 1 explains 55.598 per cent, factor 2 explains 11.543 per cent, factor 3 explains 8.914 per cent, factor 4 explains 4.027 per cent and factor 5 explains 2.648 per cent of total variance; it should be clear that these five factors explain relatively large amount of variance of 82.730 . Finally, it is concluded that the initial five variables explain relatively major part of difference whereas subsequent variables explain only small part of difference. There are five variables among all with Eigen value greater than 1 . The Eigen values related with these variables are again shown and the percentages of difference explained in the columns are labelled extraction sums of squared loadings.

Form the above table- 3 it is identified that only first five factors in Employee Green Behaviour among Employees of RINL are highly impacting aspect and the residual were of not that much. Because it only exceeds Eigen value more than 1.

Table- 4: Pattern Matrix ${ }^{\text {a- }}$ Employee Green Behaviour among Employees of RINL

\begin{tabular}{|c|c|c|c|c|c|}
\hline \multicolumn{6}{|c|}{ Pattern Matrix $^{\mathrm{a}}$} \\
\hline & \multicolumn{5}{|c|}{ Component } \\
\hline & 1 & 2 & 3 & 4 & 5 \\
\hline $\begin{array}{l}\text { Decline energy utilization by turning off } \\
\text { equipment when not being used }\end{array}$ & .971 & & & & \\
\hline $\begin{array}{l}\text { Help execute new approaches that lessen the } \\
\text { organization's effect on the climate }\end{array}$ & 969 & & & & \\
\hline $\begin{array}{l}\text { Save additional provisions or materials for a future } \\
\text { projects }\end{array}$ & .958 & & & & \\
\hline $\begin{array}{l}\text { Tidy up after an ecologically destructive mishap or } \\
\text { occasion }\end{array}$ & .933 & & & & \\
\hline $\begin{array}{l}\text { Pick a less advantageous drive since it helps the } \\
\text { climate }\end{array}$ & .922 & & & & \\
\hline $\begin{array}{l}\text { Change work cycles to decrease adverse } \\
\text { consequences on the climate }\end{array}$ & .848 & & & & \\
\hline $\begin{array}{l}\text { Reject an alluring venture since it would be awful } \\
\text { for the climate }\end{array}$ & .810 & & & & \\
\hline $\begin{array}{l}\text { Offer recognition to other employees for their } \\
\text { harmless conduct towards ecosystem }\end{array}$ & .730 & & & & \\
\hline $\begin{array}{l}\text { Push the organization's chiefs to take a stronger } \\
\text { position on Climate issues }\end{array}$ & 649 & & & & \\
\hline $\begin{array}{l}\text { Give ecologically related writing to other } \\
\text { employees }\end{array}$ & 618 & & & & \\
\hline Plan another item that contains no unsafe segments & & .946 & & & \\
\hline Not to toss recyclable materials into garbage bins & & .932 & & & \\
\hline Reuse paper, plastic, metal cans, and so on & & .904 & & & \\
\hline $\begin{array}{l}\text { Screen workplace processes for likely wellsprings } \\
\text { of accidental pollution }\end{array}$ & & .801 & & & \\
\hline $\begin{array}{l}\text { Not purposely cause pointless harm to the climate } \\
\text { through business related choices }\end{array}$ & & .733 & & & \\
\hline $\begin{array}{l}\text { Foster new work measures that utilization less } \\
\text { natural resources }\end{array}$ & & .680 & & & \\
\hline $\begin{array}{l}\text { Propose new program for the organization which is } \\
\text { harmless to the ecosystem }\end{array}$ & & & .940 & & \\
\hline $\begin{array}{l}\text { Fix support issues to forestall accidental pollution } \\
\text { and waste of resources }\end{array}$ & & & .929 & & \\
\hline $\begin{array}{l}\text { Expand the life expectancy of office hardware } \\
\text { through fix and support }\end{array}$ & & & .915 & & \\
\hline $\begin{array}{l}\text { Not to use single-use, expendable items, for } \\
\text { example, paper towels }\end{array}$ & & & .891 & & \\
\hline Design new, eco-friendly items & & & .880 & & \\
\hline $\begin{array}{l}\text { Voice worries that acting supportive of } \\
\text { environment couldn't hurt the organization }\end{array}$ & & & .873 & & \\
\hline
\end{tabular}




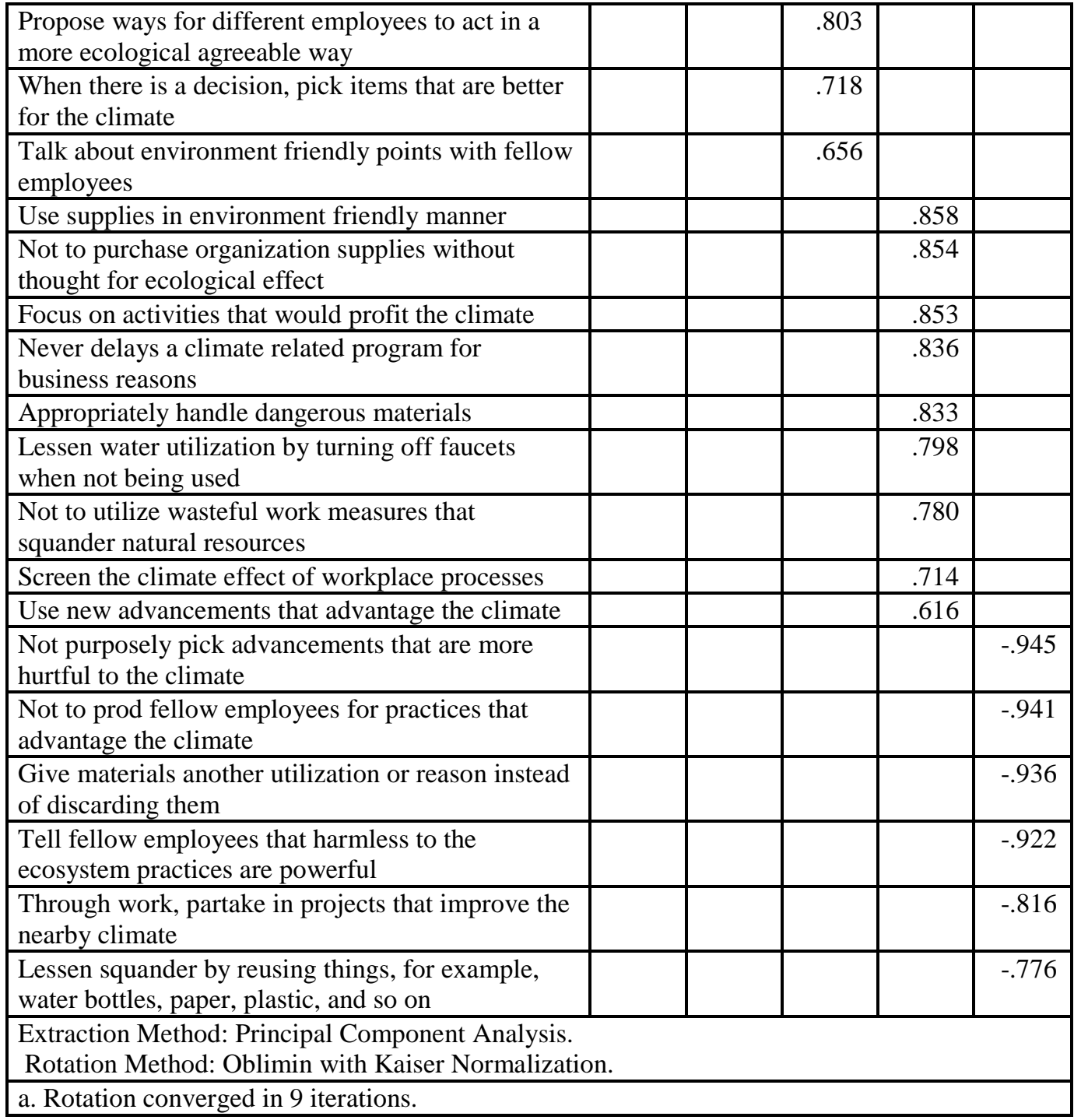

(Source: Primary Data)

Above Table- 4 shows the Pattern Matrix ${ }^{\mathrm{a}}$ Employee Green Behaviour among Employees of RINL. On the basis of Oblimin with Kaiser Normalization, five groups emerged. These five groups consist of all those factors that have factor loadings greater than or least equal to 0.5 . Thus, the first group there are ten dimensions and this group is titled as EGB1. For second component there are six dimensions and these six dimensions are combined together to get one group extracted and it is conceptualized as EGB2.
For third component there are nine dimensions and these eight dimensions are combined together to get one group extracted and it is conceptualized as EGB3. For forth component there are nine dimensions and these nine dimensions are combined together to get one group extracted and it is conceptualized as EGB4. For fifth component there are nine dimensions and these six dimensions are combined together to get one group extracted and it is conceptualized as EGB5. These five groups are considered for further study.

Table- 5: Component Correlation Matrix- Employee Green Behaviour among Employees of RINL

\begin{tabular}{|l|r|r|r|r|r|}
\hline \multicolumn{7}{|c|}{ Component Correlation Matrix } \\
\hline Component & \multicolumn{1}{c|}{1} & \multicolumn{1}{c|}{2} & 3 & \multicolumn{1}{c|}{4} & \multicolumn{1}{l|}{5} \\
\hline 1 & 1.000 & .432 & .499 & .716 & -.507 \\
\hline 2 & .432 & 1.000 & .415 & .410 & -.737 \\
\hline 3 & .499 & .415 & 1.000 & .540 & -.404 \\
\hline 4 & .716 & .410 & .540 & 1.000 & -.462 \\
\hline 5 & -.507 & -.737 & -.404 & -.462 & 1.000 \\
\hline $\begin{array}{l}\text { Extraction Method: Principal Component Analysis. } \\
\text { Rotation Method: Oblimin with Kaiser Normalization. }\end{array}$ \\
\hline
\end{tabular}

(Source: Primary Data) 
The final part of the factor analysis output is a component Correlation matrix between the factors. This matrix contains the correlation coefficients between the factors. From Table- 5 it is understood that all these factors are interrelated with each other to some degree. The fact that these correlations exists tells that the constructs measured can be interrelated. If the constructs are independent then the component correlation matrix should have been identity matrix. Therefore, from this final matrix it appears that the independence of the factors cannot be assumed.

\section{FINDINGS}

1. Total 40 questions are considered for the study.

2. 40 questions are summarised into five groups. Those five groups are EGB1, EGB2, EGB3, EGB4 and EGB5.

3. EGB1 is having highest factor loading .971 for "Decline energy utilization by turning off equipment when not being used".

4. EGB4 is having least factor loading .616 for "Use new advancements that advantage the climate".

\section{SUGGESTIONS}

1. From the analysis it is found that majority of the employees felt turning off the equipment has key role to play in decline in energy utilization. In the government organisations often it is found that fans, lights, A.C. and other equipments are left switched on even when it is not in use because of which energy utilization rises up. Therefore, organisations have to place energy utilization charts in every department so that employees can understand level of utilization of power in the department and need for decline in power utilization.

2. Employees also felt that using new advancements that advantage climate has less significant impact. The reason could be that there is much scope for the advantage for climate with the present equipment which is unused and employees felt rather than going for new advanced equipment better to efficiently use existing equipment effectively.

\section{CONCLUSION}

The present research is executed to identify the factors influencing employee green behaviour in Rashtriya Ispat Nigam Ltd. And analysis found that all 40 questions have significant impact on the employee green behaviour in the study area. 40 questions are summarised in to five groups. Those groups include EGB, EGB2, EGB3, EGB4 and EGB5.

\section{Scope for Future Research}

Current research focused on the factors influencing employee green behaviour in the study area. In future researchers can examine Green HRM, Organisational culture impact on employee green behaviour.

\section{REFERENCES}

1. Bahat, E. (2020). Person-organization fit and commitment to volunteer organizations. Voluntas 31, 1-16. doi: 10.1007/s11266-020-00212-x.

2. Bohlmann, C., van den Bosch, J., \& Zacher, H. (2018). The relative importance of employee green behavior for overall job performance ratings: A policy-capturing study. Corporate Social Responsibility and Environmental Management, 25(5), 1002-1008.

3. Buttel, F.H. (1979) Age and environmental concern: multivariate analysis. Youth and Society 10(3): 237256.

4. Cable, D. M., and DeRue, D. S. (2002). The convergent and discriminant validity of subjective fit perceptions. J. Appl. Psychol. 87, 875-884. doi: 10.1037/0021-9010. 87.5.875

5. Daily B F, Huang S. (2001). Achieving sustainability through attention to human resource factors in environmental management [J]. International Journal management [J].International Journal of operations \& Production Management, 21(12):1539-1552.

6. Dilchert S. (2012). Environmental sustainability at work: a call to action [J]. Industrial and Organizational Psychology, 5(4):444-466.

7. DuNann Winter, D., \& Koger, S. M. (2004). The psychology of environmental problems. Mahwah, NJ: Lawrence Erlbaum.

8. Gardner, G. T., \& Stern, P. C. (2002). Environmental problems and human behaviour (2nd ed.). Boston, MA: Pearson Custom Publishing.

9. Geller, E. S. (2002). The challenge of increasing proenvironmental behavior. In R. B. Bechtel, \& A. Churchman (Eds.), Handbook of environmental psychology (pp. 525-540). New York: Wiley

10. Howard, G. S. (2000). Adapting human lifestyles for the 21st Century. American Psychologist, 55, 509515.

11. Mi L, Sun $Y$, Gan X, Yang $H$, Lv T, Shang $K$, Qiao $Y$ and Jiang $Z$ (2020) Promoting Employee Green Behavior Through the Person-Organization Fit: The Moderating Effect of Psychological Distance. Front. Psychol. 11:568385. doi: 10.3389/fpsyg.2020.568385

12. Midden, C., Kaiser, F., \& McCalley, T. (2007). Technology's four roles in understanding individuals' conservation of natural resources. Journal of Social Issues, 63(1), 155-174

13. Oskamp, S. (2000). A sustainable future for humanity? American Psychologist, 55, 496-508.

14. Stem $P$ C. (2005). New environmental theories: toward a coherent theory of environment significant behaviour [J]. Journal of Social Issues, 56(3):407424.

15. Unsworth K L, Dmitrieva A, Adriasola E. (2013). Changing behaviour: increasing the effectiveness of workplace interventions in creating proenvironmental behaviour Change [J]. Journal of Organizational Bahavior, 34(2):211-229.

16. Vlek, C., \& Steg, L. (2007). Human behavior and environmental sustainability: problems, driving 
forces and research topics. Journal of Social Issues, 63(1), 1-19.

17. Winter, D. D. (2000). Some big ideas for some big problems. American Psychologist, 55, 516-522.

18. Xiaodong Chen, M. Nils Peterson, Vanessa Hull, Chuntian Lu, Graise D. Lee, Dayong Hong And Jianguo Liu (2011). Effects of attitudinal and sociodemographic factors on pro-environmental behaviour in urban China. Environmental Conservation, $\quad P p: \quad 1-\quad 8$. doi:10.1017/S037689291000086X 